\section{Morgen- und Abendprotokolle}

Helga Peter

Marburg, Deutschland

\section{Synonyme}

D-MEQ

\section{Englischer Begriff}

Morningness/Eveningness Questionnaires (MEQ)

\section{Definition}

Deutsche Version des Morningness/Eveningness Questionnaires.

Siehe auch

- \,Leistungs-, Schläfrigkeits- und Vigilanzmessung“

- „Schlaftagebücher“ 